MINERALOGIA, 44, No 3-4: 99-114 (2013)

DOI: 10.2478/mipo-2013-0006

www.Mineralogia.pl

MineRALOgICAL Society of Poland

POLSKIE TOWARZYSTWO MINERALOGICZNE

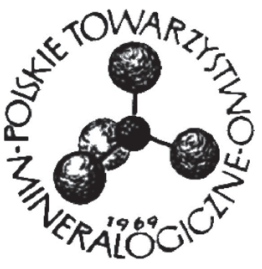

Original paper

\title{
The chevkinite group: underestimated accessory phases from a wide range of parageneses
}

\author{
Bogusław BAGIŃSKI ${ }^{1 *}$, Ray MACDONALD ${ }^{1,2}$ \\ ${ }^{1}$ IGMiP Faculty of Geology, University of Warsaw, ul. Żwirki i Wigury 93, 02-089 Warszawa, Poland; \\ e-mail: b.baginski1@uw.edu.pl \\ ${ }^{2}$ Environment Centre, Lancaster University, Lancaster LA1 4YQ, United Kingdom \\ *Corresponding author
}

Received: April 20, 2011

Received in revised form: July 27, 2013

Accepted: August 8, 2013

Available online: August 31, 2013

Abstract. Chevkinite-group minerals are widespread in a very wide range of igneous and metamorphic parageneses, forming important components of accessory mineral assemblages. Their presence in a rock may be difficult to establish by standard optical techniques, which has contributed to their importance being underestimated; a combination of SEM and EMPA is recommended here. Currently, there are eleven IMAapproved members of the group but undoubtedly several more will be described in the near future. There is considerable compositional variation in the group, which can be expressed as:

$$
\mathrm{REE}+\mathrm{M}^{2+}{ }_{\mathrm{C}}+\mathrm{M}^{3+}{ }_{\mathrm{C}}=\mathrm{Ca}^{2+}{ }_{\mathrm{A}}+\mathrm{Sr}+\mathrm{Ti}^{4+}{ }_{\mathrm{C}}+\mathrm{Zr}^{4+}{ }_{\mathrm{C}}
$$

where $\mathrm{A}$ and $\mathrm{C}$ are structural sites. Chevkinite-group minerals strongly fractionate geochemically coherent pairs, such as LREE-HREE, $\mathrm{Nb}-\mathrm{Ta}, \mathrm{Zr}-\mathrm{Hf}$ and $\mathrm{Th}-\mathrm{U}$, and thus play a critical role in geochemical modelling.

Key-words: chevkinite group minerals, chevkinite, perrierite, chemical composition, classification

\section{Introduction}

Chevkinite is normally considered to be a rare accessory mineral, occurring typically in alkaline rocks, and as a result has been relatively neglected in the literature. For example, in a recent special issue of Elements dedicated to rare earth elements (vol. 8, issue 5, 2012), chevkinite, which can contain up to $50 \mathrm{wt} \% \mathrm{REE}_{2} \mathrm{O}_{3}$, is mentioned only once. However, 
much recent work, summarised by Macdonald and Belkin (2002) and Macdonald et al. (2009), has shown that chevkinite and related phases, the chevkinite group of minerals (CGM), occur in a very wide range of igneous and metamorphic parageneses. We know of 250 localities world-wide where members of the group have been recorded and we believe that that number could easily double with further research, even on well-studied suites. For example, we have found chevkinite in such thoroughly studied rocks as the Ilímaussaq agpaitic complex, SW Greenland, and in a majority of the Palaeogene granites of Scotland and Northern Ireland, where it is the dominant REE-bearing phase (Macdonald et al. 2013).

The chevkinite group is important geochemically. They are strong concentrators of the rare earth elements (REE), $\Sigma \mathrm{REE}_{2} \mathrm{O}_{3}$ being up to $\sim 50 \mathrm{wt} \%$, and they fractionate the LREE from the HREE. Chevkinite minerals can also carry significant concentrations of $\mathrm{Zr}, \mathrm{Nb}, \mathrm{Sc}$ and $\mathrm{Th}$ and they fractionate $\mathrm{Zr}-\mathrm{Hf}, \mathrm{Nb}-\mathrm{Ta}$ and $\mathrm{Th}-\mathrm{U}$ relative to mantle and crustal abundances. Any attempts to model the evolution of magmas on the basis of REE or incompatible trace element abundances and behaviour must take account of any CGM present in the rocks. In this paper, we describe the members of the CGM, their modes of occurrence, the compositional variations in the group, some geochemical results of CGM fractionation, and the likelihood of discovering new members of the group.

\section{Members of the chevkinite group}

Eleven members of the chevkinite group are currently accepted by the International Mineralogical Association (Table 1). Two subgroups have been distinguished, the chevkinite and perrierite subgroups (Sokolova et al. 2004), containing 5 and 6 members respectively. Chevkinite-(Ce) and perrierite-(Ce) are overwhelmingly the most abundant, constituting $64 \%$ and $32 \%$, respectively, of good-quality analyses of CGM known to us. The compositions of chevkinite and perrierite closely approach the formula $\mathrm{A}_{4} \mathrm{BC}_{2} \mathrm{D}_{2} \mathrm{Si}_{4} \mathrm{O}_{22}$ (or alternatively $\mathrm{A}_{4} \mathrm{BC}_{2} \mathrm{D}_{2}\left(\mathrm{Si}_{2} \mathrm{O}_{7}\right)_{2} \mathrm{O}_{8}$ ), where $\mathrm{A}=\mathrm{REE}, \mathrm{Ca}, \mathrm{Sr}$, Th; $\mathrm{B}=\mathrm{Fe}^{2+} ; \mathrm{C}=\mathrm{Fe}^{3+}, \mathrm{Fe}^{2+}$, $\mathrm{Mn}, \mathrm{Mg}, \mathrm{Zr}, \mathrm{Nb}$; and D = Ti (Gottardi 1960; Bonatti, Gottardi 1966; Ito 1967; Ito, Arem 1971) (Table 2). Macdonald, Belkin (2002) presented an empirical discrimination between chevkinite and perrierite using $\mathrm{CaO}-\mathrm{FeO} *$ relationships, which was modified by Macdonald et al. (2009) by the addition of $\mathrm{SrO}$ to $\mathrm{CaO}$ (Fig. 1) to allow other, particularly Sr-rich, CGM members to be included in the scheme. Although empirical, the discriminant also distinguishes phases with $\beta \sim 100^{\circ}$ (chevkinite subgroup) and those with $\beta \sim 113^{\circ}$ (perrierite subgroup), the angle being the most robust difference between the two subgroups (Haggerty, Mariano 1983). The relationships between other members of the perrierite subgroup are poorly known and no compositional boundaries have yet been proposed, e.g. between perrierite and strontiochevkinite. Furthermore, allocation of cations to specific structural sites becomes more complicated in the Sr-rich members of the perrierite subgroup; rather than the standard $\mathrm{A}_{4} \mathrm{BC}_{2} \mathrm{D}_{2} \mathrm{Si}_{4} \mathrm{O}_{22}$ formulation, Miyajima et al. (2001) refer to rengeite as $\mathrm{Sr}_{4} \mathrm{ZrTi}_{4} \mathrm{Si}_{4} \mathrm{O}_{22}$ and Miyajima et al. (2002) give matsubaraite the formula $\mathrm{Sr}_{4} \mathrm{Ti}_{5}\left(\mathrm{Si}_{2} \mathrm{O}_{7}\right)_{2} \mathrm{O}_{8}$. Until there is a much fuller understanding of the relationship between mineral structure and composition in the group, the classification in Figure 1 is nevertheless a useful tool, especially in EMPA-based studies. 
Members of the chevkinite group, accepted by the CNMNC-IMA

\begin{tabular}{|c|c|c|}
\hline Mineral & Ideal formula & Reference \\
\hline \multicolumn{3}{|l|}{ Chevkinite subgroup } \\
\hline Chevkinite-(Ce) & $\left(\mathrm{REE}, \mathrm{Ca}_{4} \mathrm{Fe}^{2+}\left(\mathrm{Ti}, \mathrm{Fe}^{3+}, \mathrm{Fe}^{2+}, \mathrm{Al}_{2}\right)_{2} \mathrm{Ti}_{2} \mathrm{Si}_{4} \mathrm{O}_{22}\right.$ & Ito, Arem (1971) \\
\hline Polyakovite-(Ce) & $(\mathrm{REE}, \mathrm{Ca})_{4}\left(\mathrm{Mg}, \mathrm{Fe}^{2+}\right)\left(\mathrm{Cr}, \mathrm{Fe}^{3+}\right)_{2}(\mathrm{Ti}, \mathrm{Nb})_{2} \mathrm{Si}_{4} \mathrm{O}_{22}$ & Sokolova et al. (2001) \\
\hline Maoniupingite-(Ce) & $(\mathrm{REE}, \mathrm{Ca})_{4}\left(\mathrm{Fe}^{3+}, \mathrm{Ti}, \mathrm{Fe}^{2+}, \square\right)\left(\mathrm{Fe}^{3+}, \mathrm{Fe}^{2+}, \mathrm{Nb}, \mathrm{Ti}\right)_{2} \mathrm{Ti}_{2} \mathrm{Si}_{4} \mathrm{O}_{22}$ & Shen et al. (2005) \\
\hline Dingdaohengite-(Ce) & $\mathrm{Ce}_{4} \mathrm{Fe}^{2+} \mathrm{Ti}_{2} \mathrm{Ti}_{2}\left(\mathrm{Si}_{2} \mathrm{O}_{7}\right)_{2} \mathrm{O}_{8}$ & Xu et al. (2008) \\
\hline Christofschäferite-(Ce & $(\mathrm{Ce} . \mathrm{La}, \mathrm{Ca})_{4} \mathrm{Mn}\left(\mathrm{Ti}, \mathrm{Fe}^{3+}\right)_{3}\left(\mathrm{Fe}^{3+}, \mathrm{Fe}^{2+}, \mathrm{Ti}\right)\left(\mathrm{Si}_{2} \mathrm{O}_{7}\right)_{2} \mathrm{O}_{8}$ & Chukanov et al. (2012) \\
\hline \multicolumn{3}{|l|}{ Perrierite subgroup } \\
\hline Perrierite-(Ce) & $\left(\mathrm{REE}, \mathrm{Ca}_{4} \mathrm{Fe}^{2+}\left(\mathrm{Ti}, \mathrm{Fe}^{3+}, \mathrm{Fe}^{2+}, \mathrm{Al}\right)_{2} \mathrm{Ti}_{2} \mathrm{Si}_{4} \mathrm{O}_{22}\right.$ & Ito, Arem (1971) \\
\hline Strontiochevkinite & $\left(\mathrm{Sr}_{2}[\mathrm{La}, \mathrm{Ce}]_{1.5} \mathrm{Ca}_{0.5}\right)_{4} \mathrm{Fe}^{2+}{ }_{0.5} \mathrm{Fe}^{3+}{ }_{0.5}(\mathrm{Ti} . \mathrm{Zr})_{2} \mathrm{Si}_{4} \mathrm{O}_{22}$ & Haggerty, Mariano (1983) \\
\hline Rengeite & $\mathrm{Sr}_{4} \mathrm{ZrTi}_{4} \mathrm{Si}_{4} \mathrm{O}_{22}$ & Miyajima et al. (2001) \\
\hline Matsubaraite & $\mathrm{Sr}_{4} \mathrm{Ti}_{5}\left(\mathrm{Si}_{2} \mathrm{O}_{7}\right)_{2} \mathrm{O}_{8}$ & Miyajima et al. (2002) \\
\hline Hezuolinite & $(\mathrm{Sr}, \mathrm{REE})_{4} \mathrm{Zr}\left(\mathrm{Ti}, \mathrm{Fe}^{3+}, \mathrm{Fe}^{2+}\right)_{2} \mathrm{Ti}_{2} \mathrm{O}_{8}\left(\mathrm{Si}_{2} \mathrm{O}_{7}\right)_{2}$ & Yang et al. (2012) \\
\hline Perrierite-(La) & $(\mathrm{La}, \mathrm{Ce}, \mathrm{Ca})_{4}\left(\mathrm{Fe}^{2+}, \mathrm{Mn}\right)\left(\mathrm{Ti}, \mathrm{Fe}^{3+}, \mathrm{Al}\right)_{4}\left(\mathrm{Si}_{2} \mathrm{O}_{7}\right)_{2} \mathrm{O}_{8}$ & Chukanov et al. (2011) \\
\hline
\end{tabular}

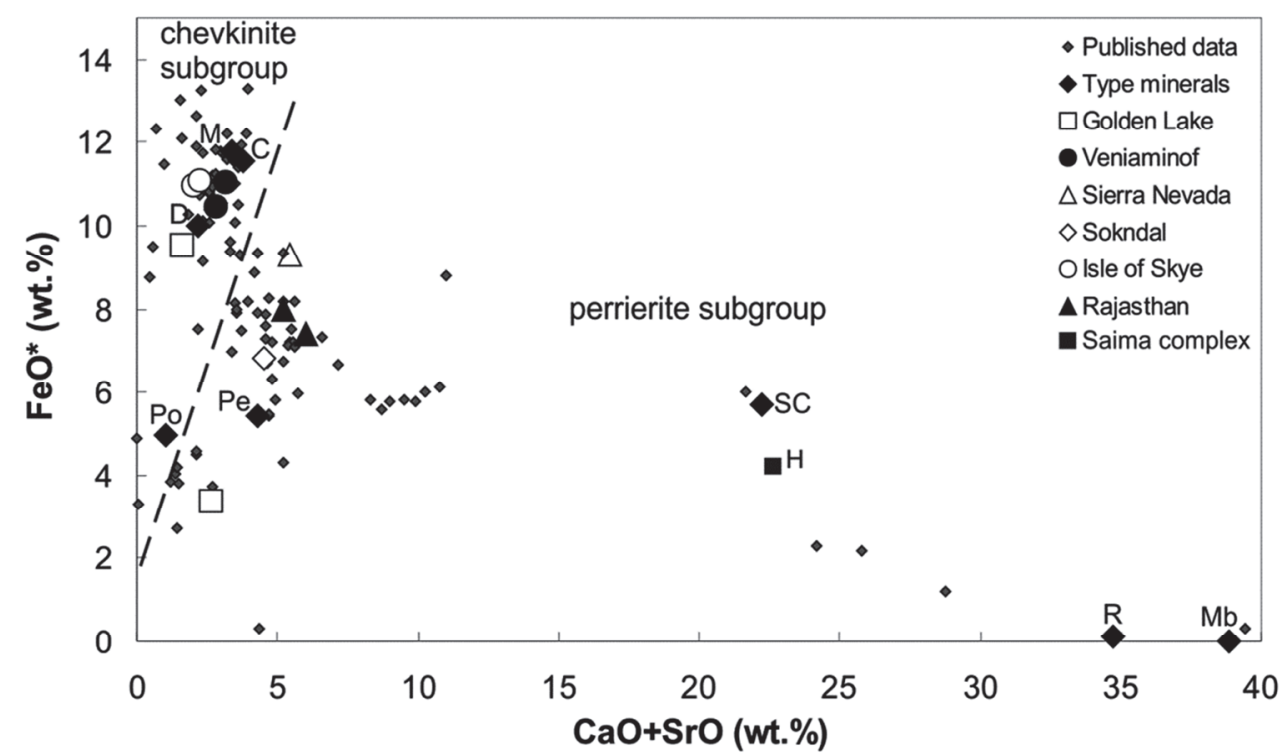

Fig. 1. Selected analyses of $\mathrm{CGM}$ plotted on the $(\mathrm{CaO}+\mathrm{SrO})-\mathrm{FeO}^{*}$ discriminatory diagram of Macdonald et al. (2009). Members of the group currently accepted by the IMA are (Table 1): M maoniupingite-(Ce); $\mathrm{C}$ - chevkinite-(Ce); D - dingdaohengite-(Ce); H - hezuolinite; Po - polyakovite(Ce); $\mathrm{Pe}$ - perrierite-(Ce); SC - strontio-chevkinite; $\mathrm{R}$ - rengeite; $\mathrm{Mb}$ - matsubaraite. Analyses of perrierite-(La) and christofschäferite-(Ce) (Table 1) have not yet been published. Other symbols are for CGM from a range of localities, from Macdonald et al. (2009). 
Composition of type minerals in the chevkinite group

\begin{tabular}{|c|c|c|c|c|c|c|c|c|}
\hline \multirow[b]{2}{*}{ Sample } & \multirow[b]{2}{*}{1} & \multicolumn{4}{|c|}{ Chevkinite subgroup } & \multicolumn{3}{|c|}{ Perrierite subgroup } \\
\hline & & 2 & 3 & 4 & 5 & 6 & 7 & 8 \\
\hline $\mathrm{Nb}_{2} \mathrm{O}_{5}$ & 1.90 & 3.98 & 0.47 & 2.79 & 0.08 & $<0.01$ & 0.24 & 0.00 \\
\hline $\mathrm{SiO}_{2}$ & 20.62 & 19.09 & 19.29 & 20.03 & 20.43 & 19.71 & 22.58 & 22.60 \\
\hline $\mathrm{TiO}_{2}$ & 15.16 & 9.49 & 18.26 & 16.05 & 18.81 & 22.78 & 29.88 & 39.06 \\
\hline $\mathrm{ZrO}_{2}$ & 0.31 & - & - & - & 0.62 & 10.60 & 9.49 & 0.00 \\
\hline $\mathrm{ThO}_{2}$ & 3.48 & 2.79 & 0.16 & 0.41 & 2.87 & $<0.01$ & - & 0.00 \\
\hline $\mathrm{Al}_{2} \mathrm{O}_{3}$ & 0.50 & - & 0.04 & 0.17 & 3.93 & 0.11 & 0.20 & 0.00 \\
\hline $\mathrm{Cr}_{2} \mathrm{O}_{3}$ & - & 7.42 & - & - & - & 0.46 & - & - \\
\hline $\mathrm{Y}_{2} \mathrm{O}_{3}$ & 0.13 & 0.38 & 0.00 & 0.02 & 0.35 & $<0.01$ & - & 0.00 \\
\hline $\mathrm{La}_{2} \mathrm{O}_{3}$ & 15.19 & 15.94 & 19.53 & 12.73 & 11.01 & 8.79 & 0,00 & 0.00 \\
\hline $\mathrm{Ce}_{2} \mathrm{O}_{3}$ & 20.52 & 24.24 & 28.08 & 23.03 & 21.53 & 8.33 & 0.38 & 0.00 \\
\hline $\mathrm{Pr}_{2} \mathrm{O}_{3}$ & 1.32 & 2.01 & - & 1.58 & 1.95 & - & 0.10 & 0.00 \\
\hline $\mathrm{Nd}_{2} \mathrm{O}_{3}$ & 3.37 & 4.76 & - & 5.64 & 6.22 & - & 0.29 & 0.00 \\
\hline $\mathrm{Sm}_{2} \mathrm{O}_{3}$ & - & 0.38 & - & 0.37 & 0.58 & - & 0.04 & 0.00 \\
\hline $\mathrm{FeO}^{*}$ & 11.55 & 4.96 & 10.00 & 11.78 & 5.41 & 5.70 & 0.10 & 0.00 \\
\hline $\mathrm{MnO}$ & 0.73 & 0.05 & - & 0.32 & 0.04 & 0.11 & - & 0.00 \\
\hline $\mathrm{MgO}$ & 0.24 & 2.61 & 1.32 & 0.17 & 0.87 & $<0.01$ & 0.00 & 0.00 \\
\hline $\mathrm{CaO}$ & 3.62 & 1.06 & 2.17 & 3.39 & 4.26 & 1.78 & 0.43 & 0.00 \\
\hline $\mathrm{SrO}$ & 0.17 & - & - & - & 0.03 & 20.48 & 34.32 & 38.84 \\
\hline $\mathrm{BaO}$ & 0.07 & - & - & - & - & 0.31 & 0.13 & 0.00 \\
\hline $\mathrm{Na}_{2} \mathrm{O}$ & 0.05 & - & 0.00 & - & b.d. & 0.05 & - & 0.00 \\
\hline Total & 98.93 & 99.16 & 99.32 & 98.48 & 98.99 & $100.37 *$ & 98.18 & 100.50 \\
\hline
\end{tabular}

b.d., below detection. -, not reported. $\mathrm{FeO}^{*}$, total $\mathrm{Fe}$ as $\mathrm{Fe}^{2+} . *$ total includes other $\mathrm{REE}=1.16$ wt.\%.

Samples: 1 - chevkinite, near Miass, Urals, Russia (Macdonald, Belkin 2002); 2 - polyakovite, Ilmen Mts, Urals, Russia (Popov et al. 2001); 3 - dingdaohengite, Bayan Obo, China; 4 - maoniupingite, Mianning, Sichuan, China (Shen et al. 2005; 5 - perrierite, Nettuno, Italy (Macdonald et al. 2009); 6 - strontio-chevkinite, Sarambi, Paraguay (Haggerty, Mariano 1983); 7 - rengeite, Itoigawa-Ohmi district, Japan (Miyajima et al. 2001); 8 - matsubaraite, Itoigawa-Ohmi district, Japan (Miyajima et al. 2002). All analyses given as in original publications.

\section{Difficulties of recognition}

Chevkinite group minerals are sorosilicates, normally crystallising in the monoclinic system. They range in colour from brownish black to deep red, lack cleavage and show very brittle fracture. When fresh, they have a strong lustre but on alteration or metamictisation appear earthy. Although CGM from pegmatites can form large, handsome, prismatic crystals (Fig. 2), in the majority of occurrences they are much smaller, $10 \mu \mathrm{m}$ to $1 \mathrm{~mm}$ (Fig. 3-5). This, plus very strong absorption, can make them difficult to recognise under the optical microscope and the CGM have been confused with, inter alia, allanite, aenigmatite, ilmenite and rutile. However, in back-scattered electron (BSE) images, CGM are very bright, often the brightest phase in the thin section (Fig. 4a). In our experience, CGM are best located using SEM scans followed by electron microprobe analysis. The process can be time-consuming but usually guarantees that any CGM present are not 
overlooked. The existence of REE-free species, such as rengeite and matsubaraite, means that the REE cannot always be used as a "prospecting tool".

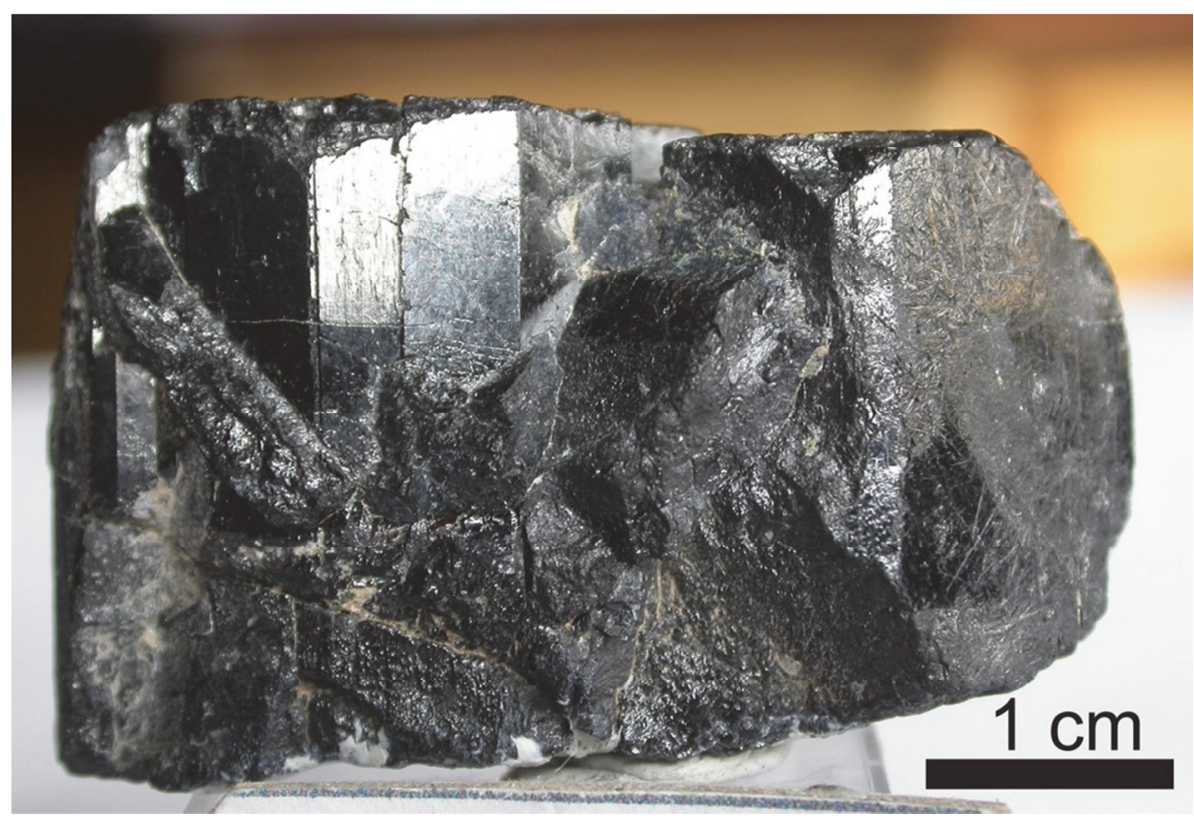

Fig. 2. Gem-quality crystal of chevkinite from Haramosh, Pakistan (B. Bagiński, collection).
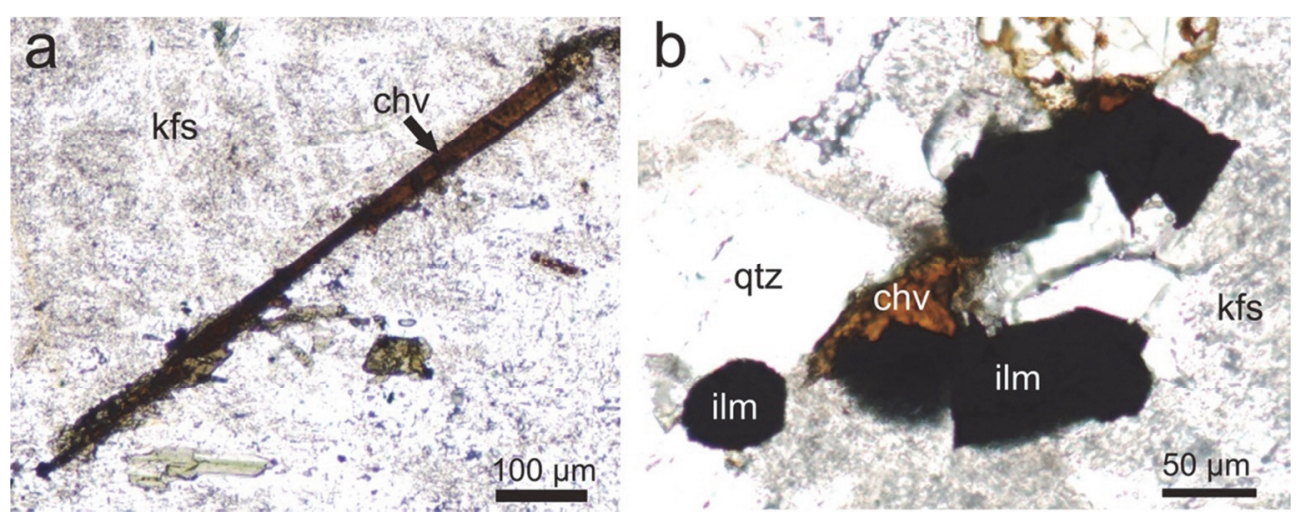

Fig. 3. (a) Acicular, reddish-brown chevkinite-(Ce) crystal in Creag Strollamus Granite, Skye, Scotland (plane polarised light). (b) Anhedral chevkinite-(Ce) mantling ilmenite in granophyre vein, Centre II, Ardnamurchan, Scotland (plane polarised light). 

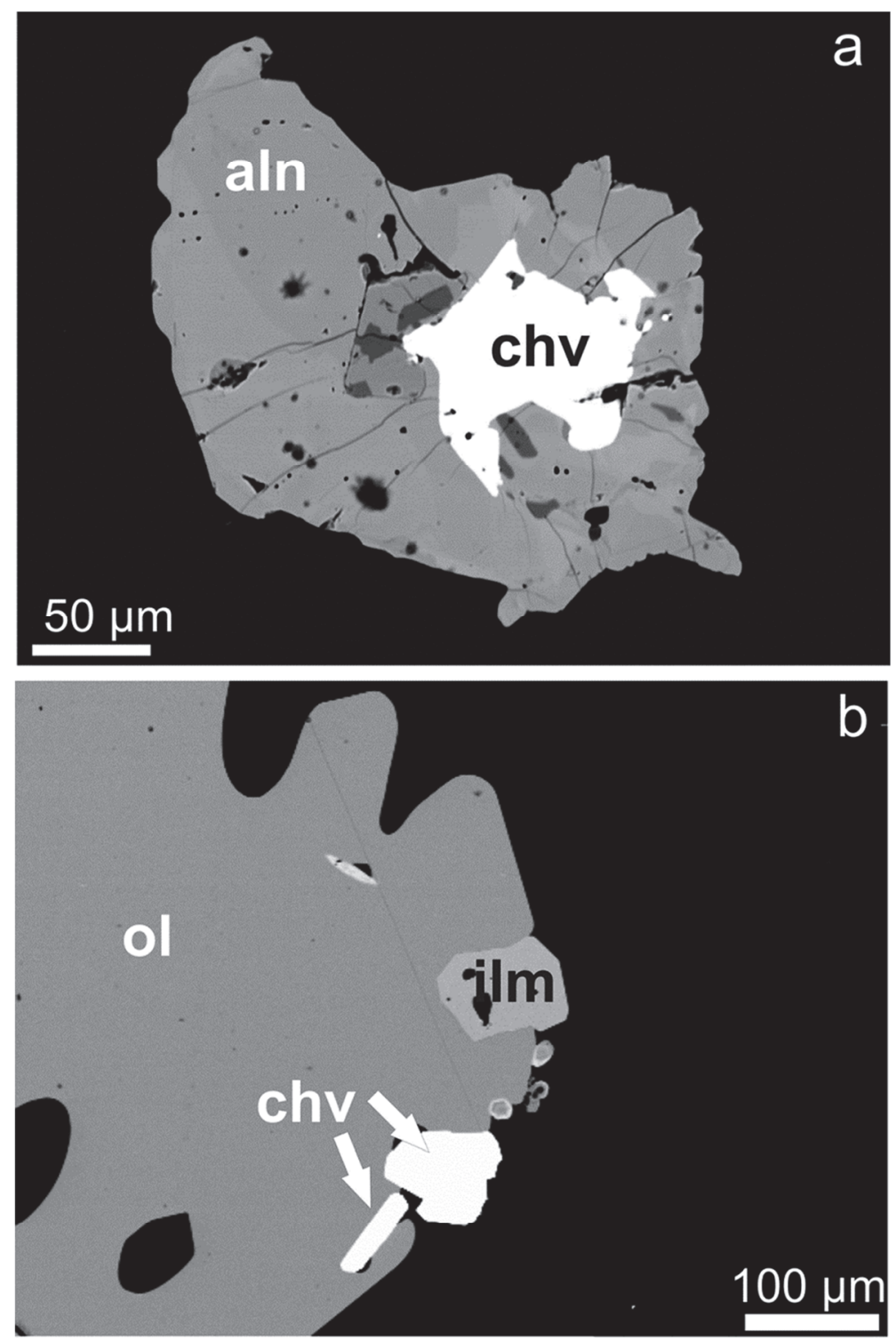

Fig. 4. (a) Chevkinite-(Ce) crystal mantled by allanite-(Ce). Note the brightness of chevkinite on this BSE image. Cumulate in G1 Granite, Mourne Mountains, Northern Ireland. (b) Chevkinite-(Ce) crystals associated with olivine phenocryst, peralkaline rhyolite, Olkaria complex, Kenya; BSE image. 

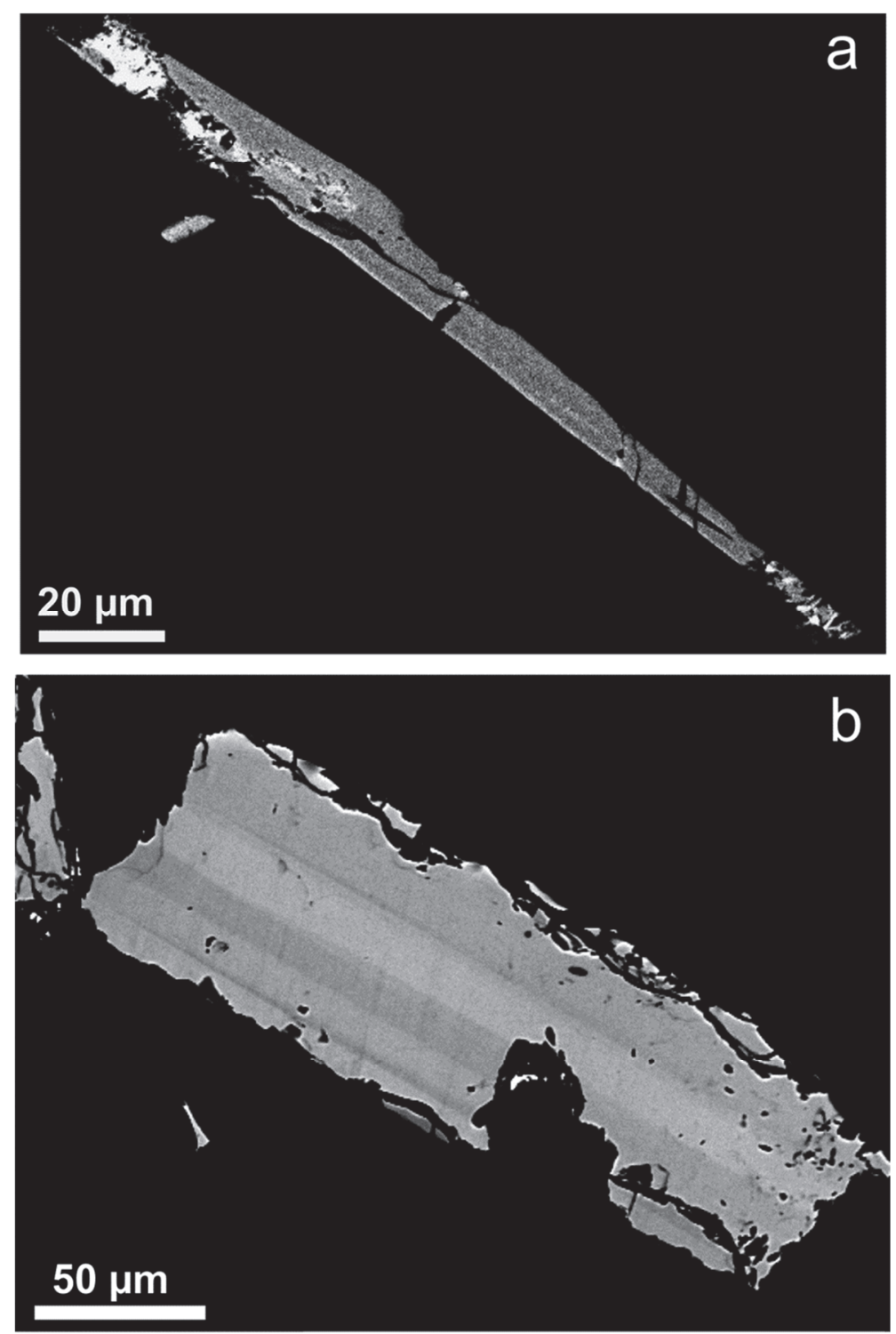

Fig. 5. (a) Acicular chevkinite in quartz crystal, Loch Ainort Granite, Skye, Scotland. (b) Zoned, partly resorbed, prismatic chevkinite-(Ce), Lava Creek Tuff, Yellowstone, USA. BSE images.

Minerals of the chevkinite group show a very wide range of habits (Fig. 3-5). One of the more common, and rather distinctive, is the acicular form shown in Figure 3a and Figure 5 a. Where they occur as phenocrysts in eruptive rocks, CGM are very often associated with the other phenocryst phases (Fig. 4b, Fig. 5b). In Figure 3b, chevkinite-(Ce) mantles ilmenite, presumably in a reaction relationship. Figure $3 \mathrm{a}$ also depicts a reaction relationship, this time of chevkinite-(Ce) to allanite-(Ce) (see more details in Macdonald et al. 2012). 


\section{Modes of occurrence}

Chevkinite is found in a wide range of rock types, including: metaluminous to peralkaline rhyolites, granites and syenites and associated pegmatites; albitites; fenites associated with carbonatite complexes; metasomatic rocks; and ore deposits. We know of only one metamorphic occurrence, in a metacarbonate at Golden Lake, Ontario (Macdonald et al. 2009). In igneous parageneses, it ranges from phenocrysts in rhyolites to late- or postmagmatic phases in the matrix of syenites and granites and in miarolitic cavities. It appears that chevkinite crystallization is restricted to relatively low temperatures, $<900^{\circ} \mathrm{C}$.

Perrierite occurs in a wider range of environments than chevkinite (Table 3). Igneous parageneses include: metaluminous rhyolites, dacites, granites, granodiorites and diorites; quartz- and nepheline-syenites and associated pegmatites; mafic-intermediate members of potassic volcanic suites; gabbroic complexes (perhaps in quartz-rich lenses); albitites; and carbonatites and associated rocks. It has been recorded, however, from only one peralkaline rhyolite, the scarcely peralkaline Tortoise Shell Mountain rhyolite, California (McCurry 1988). Perrierite has also been recorded from a range of granulite-facies rocks and associated pegmatites from Antarctica and South India. It appears that perrierite. crystallizes over a considerable P-T range, up to $1180^{\circ} \mathrm{C}$ and $10 \mathrm{kbar}$ in some Antarctic examples, and perhaps down to $\mathrm{T}<500^{\circ} \mathrm{C}$ at upper crustal pressures for some ore deposits. Neither chevkinite or perrierite seems to be particularly sensitive to oxygen fugacity; Macdonald and Belkin (2002) collated literature data on a variety of geothermobarometers and phase equilibria studies to show that they crystallised in $\mathrm{fO}_{2}$ conditions varying from below the fayalite+magnetite+quartz (FMQ) buffer to above the nickel-nickel oxide (NNO) buffer.

The ranges of occurrence of other CGM are more restricted. Strontiochevkinite is known from two localities, in rheomorphic fenites (sanidine-aegirine-nepheline dykes) associated with carbonatite plugs at Sarambi, Paraguay (Haggerty, Mariano 1983) and in nepheline syenitic pegmatites at Pegmatite Peak, Bearpaw Mountains, Montana (Chakhmouradian, Mitchell 1999). Polyakovite-(Ce) has been recorded from two very different parageneses: from a carbonatite vein of hydrothermal origin at the contact between fenites and metasomatised ultramafic rocks in the Ilmen Mountains, southern Urals, Russia (Popov et al. 2001) and as radioactive inclusions in diamonds from the River Ranch kimberlite pipe, Zimbabwe (Kopylova et al. 1997). Clearly, polyakovite-(Ce) has a very wide stability field. Rengeite was first discovered in jadeitic rocks occurring as tectonic inclusions in a serpentinite melange in the Ohmi-Itoigawa region, Japan (Miyajima et al. 2001); a second occurrence of rengeite was recorded in an albite-anorthoclase hornfels from Mt Kaskasnyunchorr, Khibiny complex, Kola, Russia by Yakovenchuk et al. (2005). An orthorhombic form of rengeite has been described by Mashima et al. (2008) from secondary veins associated with jadeitic rocks from Ohmi-Itoigawa. The same suite of rocks hosts matsubaraite, forming a prismatic crystal $\sim 0.3 \mathrm{~mm}$ long (Miyajima et al. 2002). Dingdaohengite-(Ce) is known only from magnesian skarns at the contact of granite and dolomitic marble in the Bayan Obo ore deposit in Inner Mongolia, China (Xu et al. 2008). Maoniupingite-(Ce) was identified in carbonatitic veins and alkaline rocks from the Maoniuping rare-earth deposit, Mianning, Sichuan, China (Shen et al. 2005). Hezuolinite occurs in a peralkaline nepheline syenite in the Saima alkaline complex, Liaoning Province, 
China (Yang et al. 2012). Full descriptions of perrierite-(La) and christofschäferite-(Ce), both from Mendig, Laacher See area, Germany, have not yet been published (Chukanov et al. 2011, 2012).

TABLE 3

Examples of modes of occurrence of chevkinite and perrierite

\begin{tabular}{|c|c|c|c|}
\hline Locality & Occurrence & Mineral name* & Ref \\
\hline \multicolumn{4}{|l|}{ Magmatic } \\
\hline Olkaria complex, Kenya & phenocryst in rhyolite & chevkinite-(Ce) & 1 \\
\hline Golden Lake, Labrador & accessory in metacarbonate & chevkinite-(Ce) & 2 \\
\hline Timedjelalen, Mali & accessory in syenite & chevkinite-(Ce) & 3 \\
\hline Oroscocha, Peru & accessory in kersantite & perrierite-(Ca) & 4 \\
\hline Organ Needle pluton & accessory in syenite & perrierite-(Ce) & 5 \\
\hline Joe Lott Tuff, Utah & phenocryst in rhyolite & perrierite-(Ce) & 6 \\
\hline \multicolumn{4}{|l|}{ Late- or post-magmatic } \\
\hline Roccamonfina, Italy & in miarolitic cavities & perrierite-(Ca) & 7 \\
\hline Sabatini volcano, Italy & In miarolitic cavities & perrierite-(Ca) & 8 \\
\hline \multicolumn{4}{|l|}{ Pegmatitic } \\
\hline Oslofjord, Norway & syenite & chevkinite-(Ce) & 9 \\
\hline Burley Farm, Virginia & granitoid pegmatite & perrierite-(Ce) & 2 \\
\hline Mt Charles, E. Antarctica & cutting gneisses & Al-dom. anal. of perr-(Ce) & 10 \\
\hline \multicolumn{4}{|l|}{ Metasomatic } \\
\hline Russian Platform & alkaline 'metasomite' & chevkinite-(Ce) & 11 \\
\hline Burpala massif, Russia & $\begin{array}{l}\text { aegirinised syenite } \\
\text { pegmatite }\end{array}$ & perrierite-(Ce) & 12 \\
\hline \multicolumn{4}{|l|}{ Metamorphic } \\
\hline Golden Lake, Labrador & accessory in metacarbonate & perrierite-(La) & 2 \\
\hline Granulites, E. Antarctica & in sillimanite-garnet gneiss & Al-dom. anal. of perr-(Ce) & 10 \\
\hline
\end{tabular}

* Mineral names in italics have not been IMA-approved. Names are based on the dominant cation in the A site. Al-dom. anal. of perr-(Ce) = Al-dominant analogue of perrierite-(Ce). Table modified from table 1 in Macdonald et al. (2009). References: 1 - Macdonald et al. (2002); 2 - Macdonald et al. (2009); 3 - Macdonald, Belkin (2002); 4 - Carlier, Lorand (2008); 5 - Verplanck et al. (1999); 6 - Budding et al. (1987); 7 - Della Ventura et al. (2001); 8 - Parodi et al. (1994); 9 - Segalstad, Larsen (1978); 10 - Belkin et al. (2009); 11 - Povarennikh, Ganseeva (1972); 12 - Portnov (1964).

It appears that CGM are potentially present in a very wide spectrum of igneous or metamorphic rocks and we would be loath to rule out any specific lithology as a potential host. For example, Macdonald et al. (2009) have noted that perrierite has been recorded in metaluminous granites, granodiorites and diorites (and extrusive equivalents) from at least 30 localities and have suggested that careful search will show it to be a very common, if never very abundant, phase in such rocks. In the Polish context, chevkinite group minerals 
occur in the Variscan granites in the Sudetes and in the Carboniferous alkaline intrusions of Mazury (Bagiński et al. in preparation).

\section{Some geochemical issues}

Table 4 presents analyses of chevkinite and perrierite, selected to show some of the compositional range. Despite the large ranges in individual oxides, the compositional variation in the CGM follows the general coupled substitution scheme:

$$
\mathrm{REE}+\mathrm{M}^{2+}{ }_{\mathrm{C}}+\mathrm{M}^{3+}{ }_{\mathrm{C}}=\mathrm{Ca}^{2+}{ }_{\mathrm{A}}+\mathrm{Sr}+\mathrm{Ti}^{4+}{ }_{\mathrm{C}}+\mathrm{Zr}^{4+}{ }_{\mathrm{C}}
$$

(Della Ventura et al. 2001; Vlach, Gualda 2007; Macdonald et al. 2009). For simplicity, the scheme is shown in Figure 6 for the perrierite subgroup only but it is also an excellent representation of variation in the chevkinite subgroup. Symbols on Figure 6 relate to the occurrences of the plotted points, stressing the wide range of parageneses in which the CGM are found.

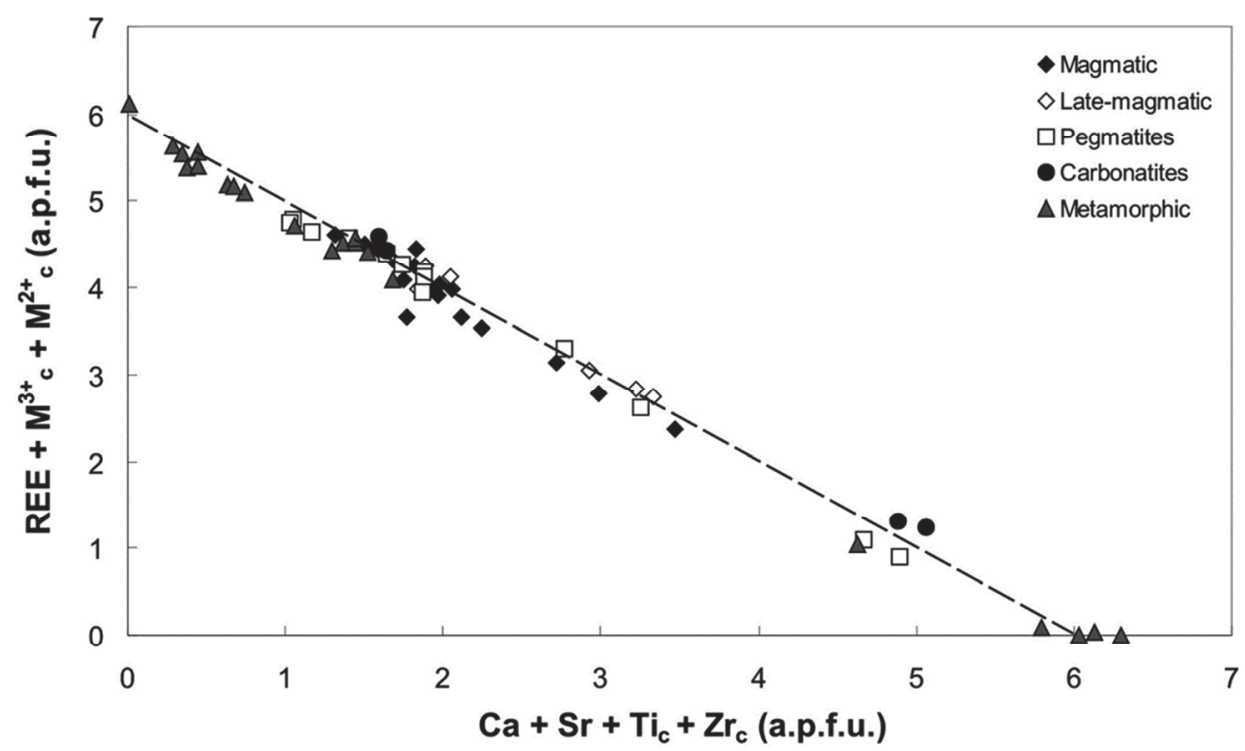

Fig. 6. Generalised coupled substitution scheme for minerals of the perrierite subgroup (from Macdonald et al. 2009). The scheme applies equally to minerals of the chevkinite subgroup.

The list (Table 4) includes three potentially new species. According to the IMACNMNC dominant-constituent rule (Hatert, Burke 2008), perrierite with $(\mathrm{Ca}+\mathrm{Sr})>$ $(\mathrm{REE}+\mathrm{Y})$ and $\mathrm{Ca}>\mathrm{Sr}$ in the $\mathrm{A}$ site is potentially perrierite-Ca, e.g. the phase from the Oroscocha volcano, Peru (Carlier, Lorand 2008). Where $(\mathrm{REE}+\mathrm{Y})>(\mathrm{Ca}+\mathrm{Sr})$ and $\mathrm{La}$ is the dominant cation, the mineral could qualify as chevkinite-(La). A mineral from Mt Cronus in the Antarctic has $\mathrm{Y}$ as the dominant cation in the $\mathrm{A}$ site and $\mathrm{Al}$ dominant in the $\mathrm{C}$ site; it is potentially the Al-dominant analogue of perrierite-(Y) (Belkin et al. 2009). Confirmation of these names, or introduction of a new terminology, must await a systematic review of chevkinite-group nomenclature by a subcommittee of the IMA-CNMNC. 
Analyses of chevkinite and perrierite, to show some of the compositional range

\begin{tabular}{|c|c|c|c|c|c|c|c|c|}
\hline & \multicolumn{3}{|c|}{ Chevkinite subgroup } & \multicolumn{5}{|c|}{ Perrierite subgroup } \\
\hline & 1 & 2 & 3 & 4 & 5 & 6 & 7 & 8 \\
\hline $\mathrm{Nb}_{2} \mathrm{O}_{5}$ & 3.82 & 3.12 & 0.23 & - & b.d. & 0.20 & 0.74 & 0.09 \\
\hline $\mathrm{SiO}_{2}$ & 20.18 & 19.01 & 19.73 & 20.30 & 19.92 & 18.34 & 23.15 & 21.18 \\
\hline $\mathrm{TiO}_{2}$ & 13.77 & 14.95 & 17.63 & 22.09 & 18.91 & 18.63 & 22.19 & 12.09 \\
\hline $\mathrm{ZrO}_{2}$ & 0.22 & 0.68 & 1.34 & 4.85 & 0.03 & 0.15 & 7.20 & b.d. \\
\hline $\mathrm{ThO}_{2}$ & 1.22 & 1.59 & 3.03 & 0.54 & b.d. & 0.62 & 0.48 & 4.13 \\
\hline $\mathrm{Al}_{2} \mathrm{O}_{3}$ & 0.30 & - & 0.53 & 0.48 & 2.06 & 0.38 & 2.15 & 8.76 \\
\hline $\mathrm{Y}_{2} \mathrm{O}_{3}$ & 0.91 & 0.80 & 1.47 & 0.90 & 0.09 & - & b.d. & 8.47 \\
\hline $\mathrm{La}_{2} \mathrm{O}_{3}$ & 12.92 & 11.70 & 10.13 & 11.63 & 22.83 & 16.44 & 9.95 & 2.17 \\
\hline $\mathrm{Ce}_{2} \mathrm{O}_{3}$ & 22.16 & 19.20 & 20.74 & 16.27 & 21.00 & 21.51 & 13.21 & 8.11 \\
\hline $\mathrm{Pr}_{2} \mathrm{O}_{3}$ & 1.97 & 1.95 & 2.12 & 0.92 & 1.20 & 3.11 & 1.63 & 1.54 \\
\hline $\mathrm{Nd}_{2} \mathrm{O}_{3}$ & 6.39 & 6.16 & 6.31 & 2.17 & 3.17 & 3.79 & 1.61 & 9.84 \\
\hline $\mathrm{Sm}_{2} \mathrm{O}_{3}$ & - & 0.83 & 0.73 & - & b.d. & - & 0.10 & 5.40 \\
\hline $\mathrm{Gd}_{2} \mathrm{O}_{3}$ & - & 0.51 & 0.51 & 0.04 & b.d. & - & 0.03 & 5.79 \\
\hline Dy2O3 & - & 0.23 & 0.13 & - & b.d. & - & b.d. & 2.76 \\
\hline $\mathrm{Yb}_{2} \mathrm{O}_{3}$ & - & 0.09 & 0.15 & 0.04 & b.d. & - & b.d. & 0.09 \\
\hline $\mathrm{FeO} *$ & 13.26 & 11.40 & 11.03 & 6.13 & 3.37 & 8.17 & 6.10 & 4.04 \\
\hline $\mathrm{MnO}$ & 0.48 & 0.15 & 0.21 & 0.93 & 0.01 & 0.48 & b.d. & b.d. \\
\hline $\mathrm{MgO}$ & 0.06 & b.d. & 0.22 & 0.11 & 2.99 & b.d. & 0.22 & 1.69 \\
\hline $\mathrm{CaO}$ & 2.30 & 3.29 & 3.14 & 3.06 & 2.52 & 1.26 & 10.83 & 1.37 \\
\hline $\mathrm{SrO}$ & b.d. & b.d. & 0.03 & 7.73 & 0.12 & 4.36 & - & - \\
\hline $\mathrm{Na}_{2} \mathrm{O}$ & b.d. & - & b.d. & 0.72 & b.d. & b.d. & b.d. & b.d. \\
\hline Total & 99.96 & $95.91 *$ & 99.41 & 98.91 & 98.22 & 97.44 & 99.59 & $98.79 * *$ \\
\hline \multicolumn{9}{|c|}{ Formulae based on 22 oxygens } \\
\hline $\mathrm{Ca}$ & 0.515 & 0.763 & 0.694 & 0.644 & 0.547 & 0.292 & 2.073 & 0.289 \\
\hline $\mathrm{Sr}$ & 0.000 & 0.000 & 0.004 & 0.880 & 0.014 & 0.546 & 0.000 & 0.000 \\
\hline $\mathrm{Na}$ & - & - & - & 0.274 & 0.000 & 0.000 & 0.000 & 0.000 \\
\hline Th & 0.058 & 0.078 & 0.143 & 0.024 & 0.000 & 0.031 & 0.020 & 0.185 \\
\hline Y & 0.100 & 0.092 & 0.161 & 0.094 & 0.010 & 0.000 & 0.000 & 0.889 \\
\hline
\end{tabular}




\begin{tabular}{|c|c|c|c|c|c|c|c|c|}
\hline $\mathrm{La}$ & 0.997 & 0.933 & 0.771 & 0.842 & 1.706 & 1.311 & 0.656 & 0.158 \\
\hline $\mathrm{Ce}$ & 1.695 & 1.521 & 1.567 & 1.169 & 1.558 & 1.702 & 0.864 & 0.586 \\
\hline $\operatorname{Pr}$ & 0.151 & 0.153 & 0.160 & 0.066 & 0.089 & 0.245 & 0.106 & 0.111 \\
\hline $\mathrm{Nd}$ & 0.477 & 0.476 & 0.465 & 0.152 & 0.229 & 0.293 & 0.103 & 0.694 \\
\hline $\mathrm{Sm}$ & - & 0.062 & 0.052 & 0.000 & 0.000 & 0.000 & 0.006 & 0.367 \\
\hline Gd & - & 0.036 & 0.035 & 0.003 & 0.000 & - & 0.000 & 0.379 \\
\hline Dy & - & 0.016 & 0.009 & 0.000 & - & - & - & 0.176 \\
\hline Sum A & 3.99 & 4.13 & 4.06 & 4.18 & 4.15 & 4.42 & 3.83 & 3.83 \\
\hline $\mathrm{Fe}^{2+}$ & 1.000 & 1.000 & 1.000 & 1.000 & 0.571 & 1.000 & 0.911 & 0.666 \\
\hline $\mathrm{Mn}$ & 0.000 & 0.000 & 0.000 & 0.000 & 0.002 & - & 0.059 & 0.000 \\
\hline $\mathrm{Mg}$ & 0.000 & 0.000 & 0.000 & 0.000 & 0.427 & 0.000 & - & 0.334 \\
\hline Sum B & 1.00 & 1.00 & 1.00 & 1.00 & 1.00 & 1.00 & 0.97 & 1.00 \\
\hline $\mathrm{Fe}^{2+}$ & 1.318 & 1.063 & 0.903 & 0.006 & 0.000 & 0.477 & 0.000 & 0.000 \\
\hline $\mathrm{Mn}$ & 0.085 & 0.027 & 0.037 & 0.155 & 0.002 & 0.088 & 0.000 & 0.000 \\
\hline $\mathrm{Mg}$ & 0.019 & 0.000 & 0.068 & 0.032 & 0.475 & 0.000 & 0.000 & 0.163 \\
\hline $\mathrm{Ti}$ & 0.163 & 0.432 & 0.737 & 1.261 & 0.881 & 1.028 & 0.981 & 0.000 \\
\hline $\mathrm{Al}$ & 0.073 & - & 0.129 & 0.096 & 0.492 & 0.061 & 0.453 & 2.033 \\
\hline $\mathrm{Zr}$ & 0.023 & 0.072 & 0.135 & 0.464 & 0.003 & 0.016 & 0.627 & 0.000 \\
\hline $\mathrm{Nb}$ & 0.362 & 0.306 & 0.021 & 0.000 & 0.000 & 0.020 & 0.060 & 0.009 \\
\hline Sum C & 2.04 & 1.90 & 2.03 & 2.01 & 1.85 & 1.69 & 2.12 & 2.21 \\
\hline $\mathrm{Ti}(=\mathrm{D})$ & 2.00 & 2.00 & 2.00 & 2.00 & 2.00 & 2.00 & 2.00 & 1.79 \\
\hline $\mathrm{Si}$ & 4.216 & 4.113 & 4.071 & 3.985 & 4.035 & 3.964 & 4.135 & 4.162 \\
\hline $\mathrm{Al}$ & 0.000 & 0.000 & 0.000 & 0.015 & 0.000 & 0.036 & 0.000 & 0.000 \\
\hline Sum T & 4.22 & 4.11 & 4.07 & 4.00 & 4.04 & 4.00 & 4.14 & 4.16 \\
\hline CatSum & 13.2 & $13.2 * * *$ & 13.2 & 13.2 & 13.0 & 13.1 & 13.1 & $13.1 * * * *$ \\
\hline
\end{tabular}

b.d., below detection. Blank, not determined. $\mathrm{FeO}^{*}$, total $\mathrm{Fe}$ as $\mathrm{Fe}^{2+}$. CatSum - sum of cations.

* - total includes $\mathrm{Tb}_{2} \mathrm{O}_{3} 0.05, \mathrm{Ho}_{2} \mathrm{O}_{3} 0.04, \mathrm{Er}_{2} \mathrm{O}_{3} 0.08, \mathrm{Tm}_{2} \mathrm{O}_{3} 0.01, \mathrm{UO}_{2} 0.03$. $\mathrm{HfO}_{2} 0.03, \mathrm{ZnO} 0.01$

** - total includes $\mathrm{Eu}_{2} \mathrm{O}_{3} 0.49, \mathrm{Ho}_{2} \mathrm{O}_{3} 0.23, \mathrm{PbO} 0.55$.

*** - sum includes $(\mathrm{Tb}+\mathrm{Ho}+\mathrm{Er}+\mathrm{Tm}+\mathrm{U}+\mathrm{Hf}+\mathrm{Zn})=0.026$

**** - sum includes Eu 0.033, Ho 0.014. Pb 0.029

Samples: 1 - Nb-rich chevkinite-(Ce), Cerro Toledo, New Mexico (Macdonald, Belkin 2002); 2 - chevkinite-(Ce), Olkaria complex, Kenya (Macdonald et al. 2007); 3 - Th-rich chevkinite-(Ce), Veniaminoff volcano, Alaska (Macdonald et al. 2009); 4 - Sr-Zr-rich perrierite-(Ce), Burpala, Russia (Portnov 1964); 5 - potentially perrierite(La), Golden Lake, Ontario (Macdonald et al. 2009); 6 - Sr-rich perrierite-(Ce), Bearpaws, Montana (Chakhmouradian, Mitchell 1999); 7 - Ca-rich perrierite-(Ce), Oroscocha volcano, Peru (Carlier, Lorand 2008); 8 - potentially Al-dominant analogue of perrierite-(Y), Mt Cronus, East Antarctica (Belkin et al. 2009)

The ranges of the more abundant minor elements in chevkinite and perrierite are presented in Table 5. The high concentrations provide some optimism that further new species will eventually be recorded. For example, Doelter (1931) presented an analysis of a phase from the Ilmen Mountain, Urals, that he termed thoriochevkinite. With Th $=$ 
$1.01 \mathrm{apfu}\left(20.91 \mathrm{wt} \% \mathrm{ThO}_{2}\right)$, this is strictly thorian chevkinite. Similarly, the so-called niobochevkinite reported from the Ilmen Mountain by Makarochkin et al. (1959) has 0.71 apfu $\mathrm{Nb}\left(7.40 \mathrm{wt} \% \mathrm{Nb}_{2} \mathrm{O}_{5}\right)$ and is niobian chevkinite-(Ce). Semenov et al. (1966) described scandium-perrierite from pegmatites in southeastern Kazakhstan, with $\mathrm{Sc}_{2} \mathrm{O}_{3}=4.14 \mathrm{wt} \%$ but the quality of their analysis has been questioned by Macdonald et al. (2009).

TABLE 5

Compositional ranges of selected elements in chevkinite group minerals

\begin{tabular}{lllll}
\hline & $\begin{array}{l}\text { chevkinite } \\
\text { oxide, wt } \%\end{array}$ & a.p.f.u. & $\begin{array}{l}\text { perrierite } \\
\text { oxide, wt } \%\end{array}$ & a.p.f.u. \\
\hline $\mathrm{Mn}$ & $0.04-5.00$ & $0.00-0.90$ & $0.01-1.96$ & $0.00-0.35$ \\
$\mathrm{Nb}$ & $0.05-7.40$ & $0.00-0.71$ & $0.04-3.96$ & $0.00-0.35$ \\
$\mathrm{Sc}$ & $0.02-4.14$ & $0.00-0.76$ & $0.03-3.26$ & $0.00-0.57$ \\
$\mathrm{Th}$ & $0.05-20.91$ & $0.00-1.01$ & $0.03-4.60$ & $0.00-0.20$ \\
$\mathrm{Zr}$ & $0.01-2.71$ & $0.00-0.27$ & $0.03-7.20$ & $0.00-0.62$ \\
\hline
\end{tabular}

The REE-bearing accessory phases show large compositional differences between different lithologies and in individual rocks as crystallization proceeded. They show, however, differing REE fractionation patterns. For example, chevkinite and allanite, with which it may be confused during routine petrographic examination, both fractionate the LREE relative to the MREE and HREE. LREE/MREE and LREE/HREE ratios in allanite are about three times those in chevkinite, such that residual melts from fractional crystallization of allanite become LREE-depleted more rapidly than through chevkinite fractionation. Misidentifying chevkinite as allanite, or missing its presence in the rock altogether, will lead to significant errors in geochemical models based on the REE. The ability of both phases to deplete residual melts in REE, and to fractionate the REE, is obviously maximised when they occur as phenocryst phases.

The ranges of selected trace element ratios in chevkinite and perrierite and average concentrations in primitive mantle (Sun, MacDonough 1989) and bulk continental crust (Taylor, McLennan 1985) are: $\mathrm{Zr} / \mathrm{Hf} \sim 2-184,36.2,33.3$; Nb/Ta 1-113, 17.4, 11.0; Th/U $\sim 2-93,4.0,3.8)$. Although some of these ranges may be due to the uncertainties inherent in analysing Hf, Ta and $\mathrm{U}$ at low concentrations (down to hundreds of ppm), it is nevertheless clear that chevkinite and perrierite have the potential to fractionate these geochemically coherent pairs of elements relative to their mantle and crustal values. Chevkinite-(Ce) is also a strong concentrator of Ge; phenocrysts from a peralkaline rhyolite from the Olkaria volcanic complex, Kenya, had a Ge concentration of $309 \mathrm{ppm}$ and an apparent mineral/melt partition coefficient of 124 (Macdonald et al. 2007). Another rhyolite from the same complex contains chevkinite-(Ce) phenocrysts with 364 ppm Ga and an apparent partition coefficient of 12 (Macdonald et al. 2010). The CGM may have important, and as yet poorly understood, roles to play in the sequestering of rare elements during crystal fractionation and partial melting. 
Acknowledgements: We are grateful to the organisers of the conference "Alkaline rocks: petrology, mineralogy, geochemistry" held in Kiev, where the topic was first presented. We also acknowledge financial support of BST 160600/4 project from IGMiP, University of Warsaw. Authors would like to thank reviewers for constructive remarks that improved the quality of the paper.

\section{References}

Arem, J.E., \& Ito, J. (1971). Chevkinite and perrierite: synthesis, crystal growth, and polymorphism. American Mineralogist, 56, 307-319.

Belkin, H.E., Macdonald, R., \& Grew, E.S. (2009). Perrierite from granulite facies metamorphic rocks and associated pegmatites of East Antarctica and South India. Mineralogical Magazine, 73(1), 149-164.

Bonatti, S., \& Gottardi, G. (1966). Un caso di poliformisma a strati in sorosilicati; perrierite and chevkinite. Periodico di Mineralogia, 35, 65-91.

Budding, K.E., Cunningham, C.G., Zielinski, R.A., Steven, T.A., \& Stern, C.R. (1987). Petrology and chemistry of the Joe Lott Tuff Member of the Mount Belknap volcanics, Marysvale volcanic field, west-central Utah. U.S. Geological Survey Professional Paper, 1354, 47 pp.

Carlier, G., \& Lorand, J.-P. (2008). Zr-rich accessory minerals (titanite, perrierite, zirconolite, baddeleyite) record strong oxidation associated with magma mixing in the South Peruvian potassic province. Lithos, 104(1-4), 5470. DOI: 10.1016/j.lithos.2007.11.008.

Chakhmouradian, A.R., \& Mitchell, R.H. (1999). Primary, agpaitic and deuteric stages in the evolution of accessory $\mathrm{Sr}, \mathrm{REE}, \mathrm{Ba}$ and $\mathrm{Nb}$-mineralization in nepheline-syenite pegmatites at Pegmatite Peak, Bearpaw Mountains, Montana. Mineralogy and Petrology, 67(1-2), 85-110. DOI: 10.1007/BF01165118.

Chukanov, N.V., Aksenov, S.M., Rastsvetaeva, R.K., Belakovskiy, D.I. Göttlicher, J., Britvin, S.N. and Van, K.V. (2012). Christofschäferite-(Ce), IMA 2011-107. CNMNC Newsletter No. 13, June 2012, page 810; Mineralogical Magazine, 76, 807-817.

Chukanov, N.V., Blaß, G., Pekov, I.V., Belakovsky, D.I., Van, K.V., Rastsvetaeva,R.K. and Aksenov, S.M. (2011). Perrierite-(La), IMA 2010-089. CNMNC Newsletter No. 9, August 2011, page 2537; Mineralogical Magazine, 75, 2535-2540.

Della Ventura, G., Williams, C.T., Raudsepp, M., Bellatreccia, F., Caprilli, E., \& Giordano, G. (2001). Perrierite(Ce) and zirconolite from a syenitic ejectum of the Roccamonfina volcano (Latium, Italy): implications for the mobility of $\mathrm{Zr}$, Ti and REE in volcanic environments. Neues Jahrbuch für Mineralogie Monatshefte, 9, 385 402.

Doelter, C. (1931). Handbuch der Mineralchemie. Volume 3. ; Dresden: Verlag von Theodor Steinkopff.

Gottardi, G. (1960). The crystal structure of perrierite. American Mineralogist, 45(1-2), 1-14.

Haggerty, S.E., \& Mariano, A.N. (1983). Strontian-loparite and strontio-chevkinite: Two new minerals in rheomorphic fenites from the Parana Basin carbonatites, South America. Contributions to Mineralogy and Petrology, 84(4), 365-381. DOI: 10.1007/BF01160288.

Hatert, F., \& Burke, E.A.J. (2008). The IMA-CNMNC dominant-constituent rule revisited and extended. The Canadian Mineralogist, 46, 717-728. DOI : 10.3749/canmin.46.3.717.

Ito, J. (1967). A study of chevkinite and perrierite. American Mineralogist, 52, 1094-1104.

Kopylova, M.G., Gurney, J.J., \& Daniels, L.R.M. (1997). Mineral inclusions in diamonds from the River Ranch kimberlite, Zimbabwe. Contributions to Mineralogy and Petrology, 129(4), 366-384. DOI: 10.1007/s004100050343.

Macdonald, R., \& Belkin, H.E. (2002). Compositional variation in minerals of the chevkinite group. Mineralogical Magazine, 66(6), 1075-1098. DOI: 10.1180/0026461026660078.

Macdonald, R., Bagiński, B., Dzierżanowski, P., Fettes, D.J. \& Upton, B.G.J. (2013). Chevkinite-group minerals in UK Palaeogene granites: underestimated REE-bearing accessory phases. The Canadian Mineralogist, 51(2), 333-347. DOI: 10.3749/canmin.51.2.333. 
Macdonald, R., Bagiński, B., Kartashov, P., Zozulya, D., Dzierżanowski, P. (2012). Chevkinite-group minerals from Russia and Mongolia: New compositional data metasomatite and ore deposits. Mineralogical Magazine, 76(3), 535-549. DOI:10.1180/minmag.2012.076.3.06,

Macdonald, R., Marshall, A.S., Dawson, J.B., Hinton, R.W., \& Hill, P.G. (2002). Chevkinite-group minerals from salic volcanic rocks of the East Africa Rift. Mineralogical Magazine, 66(2), 287-299. DOI: 10.1180/0026461026620029.

Macdonald, R., Belkin, H.E., Wall, F., \& Bagiński, B. (2009). Compositional variation in the chevkinite group: new data from igneous and metamorphic rocks. Mineralogical Magazine, 73(5), 777-796. DOI:10.1180/minmag.2009.073.5.777.

Macdonald, R., Rogers, N.W., Bagiński, B., \& Dzierżanowski, P. (2010). Distribution of gallium between phenocrysts and melt in peralkaline salic volcanic rocks, Kenya Rift Valley. Mineralogical Magazine, 74(2), 351-363. DOI:10.1180/minmag.2010.074.2.351.

Macdonald, R., Rogers, N.W., \& Tindle, A.G. (2007). Distribution of germanium between phenocrysts and melt in peralkaline rhyolites from the Kenya Rift Valley. Mineralogical Magazine, 71(6), 703-713. DOI: DOI:10.1180/minmag.2007.071.6.703.

Makarochkin, B.A., Gonibesova, K.A., \& Makarochkina, M.S. (1959). Chevkinite from the Ilmen Mountains. Zapiski Vserossiiskogo Mineralogicheskogo Obshchestva USSR, 88(5), 547-553 (in Russian).

Mashima, H., Akai, J., Nakamuta, Y., \& Matsubara, S. (2008). Orthorhombic polymorph of rengeite from Ohmi region, central Japan. American Mineralogist, 93, 1153-1157.

McCurry, M. (1988). Geology and petrology of the Woods Mountains Volcanic Center, southeastern California: implications for the genesis of peralkaline rhyolite ash flow tuffs. Journal of Geophysical Research, 93(B12), 14835-14855. DOI: 10.1029/JB093iB12p14835.

McDowell, S.D. (1979). Chevkinite from the Little Chief granite porphyry stock, California. American Mineralogist, 64, 721-727.

Miyajima, H., Matsubara, S., Miyawaki, R., Yokoyama, K., \& Hirokawa, K. (2001). Rengeite, $\mathrm{Sr}_{4} \mathrm{ZrTi}_{4} \mathrm{Si}_{4} \mathrm{O}_{22}$, a new mineral, the $\mathrm{Sr}-\mathrm{Zr}$ analogue of perrierite from the Itoigawa-Ohmi district, Niigata Prefecture, central Japan. Mineralogical Magazine, 65(1), 111-120.

Miyajima, H., Miyawaki, R., Ito, K. (2002). Matsubaraite, $\mathrm{Sr}_{4} \mathrm{Ti}_{5}\left(\mathrm{Si}_{2} \mathrm{O}_{7}\right)_{2} \mathrm{O}_{8}$, a new mineral, the Sr-Ti analogue of perrierite in jadeitite from the Itoigawa-Ohmi district, Niigata Prefecture, Japan. European Journal of Mineralogy, 14(6), 1119-1128. DOI: 10.1127/0935-1221/2002/0014-1119.

Parodi, G.C., Della Ventura, G., Montana, A., Raudsepp, M. (1994). Zr-rich non metamict perrierite-(Ce) from holocrystalline ejecta in the Sabatini volcanic complex (Latium, Italy). Mineralogical Magazine, 58(393), 607-613.

Popov, V.A., Pautov, L.A., Sokolova, E., Hawthorne, F.C., McCammon, C., \& Bazhenova, L.F. (2001). Polyakovite-(Ce), (REE,Ca) $)_{4}\left(\mathrm{Mg}, \mathrm{Fe}^{2+}\right)\left(\mathrm{Cr}^{3+}, \mathrm{Fe}^{3+}\right)_{2}(\mathrm{Ti}, \mathrm{Nb})_{2} \mathrm{Si}_{4} \mathrm{O}_{22}$, a new metamict mineral species from the Ilmen Mountains, southern Urals, Russia: mineral description and crystal chemistry. The Canadian Mineralogist, 39(4), 1095-1104. DOI:10.2113/gscanmin.39.4.1095.

Portnov, A.M. (1964). Strontium perrierite in the North Baikal region. Doklady of the Academy of Science USSR: Earth Sciences Section, 156, 118-120.

Segalstad, T.V., \& Larsen, A.O. (1978). Chevkinite and perrierite from the Oslo region, Norway. American Mineralogist, 63, 499-505.

Semenov, Y.I., Kulakov, M.P., Kostynina, M.Y.,. Kazakova, M.Y., \& Dudykina, A.S., (1966). Scandium content in the quartz-fluorite pegmatites of Kazakhstan. Geokhimiya, 2, 244-246.

Shen, G., Yang, G., \& Xu, J. (2005). Maoniupingite-(Ce): A new rare-earth mineral from the Maoniuping rareearth deposit in Mianning, Sichuan, China. Sedimentary Geology and Tethyan Geology, 25, $210-216$ (in Chinese with English abstract).

Sokolova, E., Hawthorne, F.C., Della Ventura, G., \& Kartashov, P.M. (2004) Chevkinite-(Ce): crystal structure and the effect of moderate radiation-induced damage on site-occupancy refinement. The Canadian Mineralogist, 42(4), 1013-1025. DOI: 10.2113/gscanmin.42.4.1013. 
Sun, S.-S., \& McDonough, W.F. (1989). Chemical and isotopic systematics of oceanic basalts: implications for mantle composition and processes. In A.D. Saunders \& M.J. Norry (Editors), Magmatism in the Ocean Basins. Special Publication, Geological Society, London, 42, 315-345.

Taylor, S.R., \& McLennan, S.M. (1985). The Continental Crust: Its Composition and Evolution. Blackwell, Oxford, UK, 312 pp.

Verplanck, P.L., Farmer, G.L., McCurry, M., \& Mertzman, S.A. (1999). The chemical and isotopic differentiation of an epizonal magma body: Organ Needle pluton, New Mexico. Journal of Petrology, 40(4), 653-678. DOI: 10.1093/petroj/40.4.653.

Vlach, S.R.F., Gualda, G.A.R. (2007). Allanite and chevkinite in A-type granites and syenites of the Graciosa Province, southern Brazil. Lithos, 97, 98-121. DOI:10.1016/j.lithos.2006.12.003.

Xu, J., Yang, G., Li, G., Wu, Z., \& Shen, G. (2008). Dingdaohengite-(Ce) from the Bayan Obo REE-Nb-Fe mine, China: Both a true polymorph of perrierite-(Ce) and a titanic analog at the $C 1$ site of chevkinite subgroup. American Mineralogist, 93, 740-744.

Yakovenchuk, V.N., Ivanyuk, G.Yu.,. Pakhomovsky, Ya.A., \& Menshikov, Yu.P. (2005). Khibiny. F. Wall, F. (Ed.), Laplandia Minerals: Apatity. Published in association with the Mineralogical Society of Great Britain and Ireland. $468 \mathrm{pp}$.

Yang, Z., Ding, K., Giester, G. and Tillmans, E. (2012). Hezuolinite, $(\mathrm{Sr}, \mathrm{REE})_{4} \mathrm{Zr}\left(\mathrm{Ti}, \mathrm{Fe}^{3+}, \mathrm{Fe}^{2+}\right)_{2} \mathrm{O}_{8}\left(\mathrm{Si}_{2} \mathrm{O}_{7}\right)_{2}$, a new mineral species of the chevkinite group from Saima alkaline complex, Liaoning Province, NE China. European Journal of Mineralogy, 24(1), 189-196. DOI: 10.1127/0935-1221/2011/0023-2158. 